\title{
Introduction to Argentine exceptionalism
}

\author{
Edward L. Glaeser ${ }^{1} \cdot$ Rafael Di Tella ${ }^{1} \cdot$ Lucas Llach $^{2}$
}

Received: 25 September 2017/Revised: 29 September 2017/ Accepted: 27 October 2017

(C) The Author(s) 2018. This article is an open access publication

\begin{abstract}
This article is an introduction to the special collection on Argentine Exceptionalism. First, we discuss why the case of Argentina is generally regarded as exceptional: the country was among the richest in the world at the beginning of the 20th century, but it gradually lost this place of privilege. We discuss that most explanations regarding the hypothesis of Argentine Exceptionalism fall into one or several of four categories. The first explanation is to challenge the exceptionalism hypothesis, either by arguing that the country was not so rich at the beginning of the 20 th century or that it is not so poor now. The second explanation states that the country failed to generate growth supporting institutions despite its wealth, thus leading to a relative decline in its income level. The next explanation is that the country faced a series of adverse external shocks which disfavored what had been a successful growth model. Finally, scholars have also stated that exceptionalism is a consequence of poor policy choices, in particular a tendency towards state intervention and isolationism. Next, we introduce the remaining papers of the special collection and how they relate to the aforementioned hypothesis. Finally, we offer some concluding remarks regarding this article.
\end{abstract}

Keywords Argentine exceptionalism · Economic history

JEL Classification N10 - N16 D78

Rafael Di Tella

rditella@hbs.edu

1 Harvard University and NBER, Cambridge, USA

2 Banco Central de la República Argentina, Buenos Aires, Argentina 


\section{Introduction}

Argentina began the 20th century as one of the wealthiest places on the planet. In 1913, it was richer than France or Germany, almost twice as prosperous as Spain, and its per capita GDP was almost as high as that of Canada. Until the 1930s, the French used the phrase "riche comme un Argentin" to describe the foolishly rich. The century's golden beginning was followed by far less prosperous decades. Over the last 100 years, Argentina's place in the hierarchy of nations dropped precipitously, falling behind not only Europe but also many of the growing countries in Asia.

Why did a nation that was doing so well end up doing so poorly? Argentina's mediocre 20th century performance matters not only for students of Latin American economic history. That performance stands as a warning to the world. No country is too rich to fail. The set of essays in this journal collects different perspectives that attempt to make sense of what went wrong in Argentina, in the hope that more knowledge will improve Argentina's future and help other nations to avoid future pitfalls. This special collection was the brainchild of John S. Reed, whose generosity is only matched by his intellectual curiosity and care for Argentina.

This introductory essay reviews the seven papers included in this special collection dedicated to exploring the puzzle of Argentina's economic performance during the 20th century. Section II begins by summarizing the facts. We rely, like much of the research community, on the data gathered by Angus Maddison, supplementing it with other sources. There is some controversy regarding whether Argentina was really wealthier than Western Europe, but there is little doubt that Argentina was, in fact, quite prosperous by world standards.

That prosperity was not shared equally across Argentines, but that was hardly unusual. Between 1870 and 1930, Argentina experienced robust growth and remained wealthy by world standards. Between 1930 and 1970, Argentina continued growing, but at a slower pace than the world as a whole. By 1975, Argentina's income had slipped to being 60\% of incomes in France. Then, after 1970, Argentina stagnated and during some years even declined. Argentina's 20th century path serves as a cautionary tale about how a wealthy country can lose its way.

In Sect. III, we outline four basic hypotheses present in the literature on Argentina's economic decline. The first hypothesis suggests that Argentina's decline is not exceptional after all-maybe Argentina was not really rich, in a broad sense of the word, by 1929, and maybe, recent figures underestimate the growth in GDP (and welfare) due to critical structural changes. The other three hypotheses emphasize bad institutions (e.g., a Democracy too weak to defend itself), bad policies, and bad luck in international markets.

Of course, this classification is only an attempt to order the discussion, as each of the four hypotheses admits several variations and often complement one another. ${ }^{1}$ Bad policies often emanate from bad institutions. Indeed, a feature of the seven papers in this special collection is that they are related to each other as, typically, the economic factors

\footnotetext{
1 In fact, Lagos and Llach (2011) list as many as 38 different hypotheses advanced by the literature on the causes of the Argentine decline. On alternative systems of classifications, see Borges (1952).
} 
that bedeviled Argentina reinforced each other. Section IV of this essay presents and summarizes the papers and ties them to one or more of the four hypotheses.

Finally, in Sect. V, we emphasize the core themes running through the essays in this special collection. Argentina was different at the start of the 20th century: it had less education, technology, and probably also weaker political institutions. Those factors made Argentina particularly vulnerable to economic shocks and that vulnerability led to dire political consequences. The lack of human capital also made it particularly hard to find new ways to grow throughout most of the past one hundred years, especially when global changes challenged a previously successful economic model. Argentina's bad 20th century is surprising, but it is not inexplicable. It is the outcome of adverse shocks, and policies that responded to those shocks, impacting a country that had only natural-resource-driven prosperity.

\section{The basic puzzle}

Was Argentina's growth experience during the 20th century an exceptional one? In terms of its rate of growth it certainly was, at least after the first couple of decades. Figure 1 provides a starting point for the questions posed in this special collection. It shows Argentina's per capita GDP expressed as a percentage of 12 rich nations' income per capita. Amidst many short-run fluctuations, the longer term lackluster pattern stands

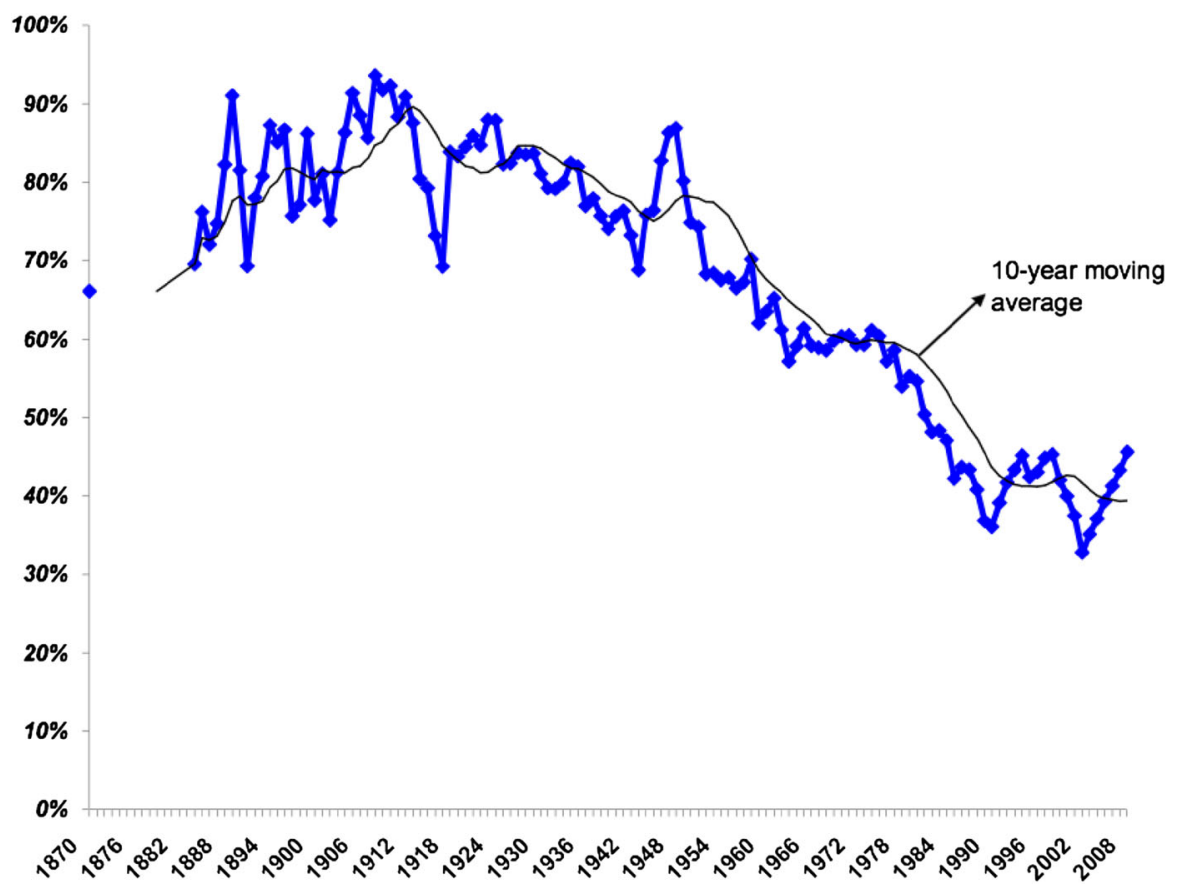

Fig. 1 Argentina's GDP as a percentage of twelve rich countries Source: Own elaboration based on Maddison Project, http://www.ggdc.net/maddison/, retrieved March 2010 
clear. In 1870, Argentina's per capita GDP was two-thirds of the rich country average. By the beginning of the 20th century, Argentina's output had risen to nine-tenths. After a brief crisis during World War I and recovery afterwards, a long relative decline ensued, with two prominent exceptions. Argentina enjoyed a short spurt in the late forties, which were the early Perón years and in the immediate aftermath of World War II. Argentina kept pace with the other wealthy nations during the 1960s. Relative decline accelerated after 1975, and by 1990, Argentina had reached a level of around one-third of these (relatively rich) countries' per capita GDP. In the last two decades, Argentina's prosperity has fluctuated wildly, but the downward trend seems to have subsided. Still, there is not still recovery in the income ratio with the rich.

If we use 1928 as a base year, which was probably the final year of Argentina's own belle époque as well as the end of America's Roaring 20s, we see that no other country of major economic significance took so long to double its per capita GDP. This feat was achieved by Argentina only in 2000. During the same period, the richest members of the "convergence club" (Britain, US, Canada, Belgium, Netherlands, and Australia) multiplied their income by around 4. Other currently developed countries saw their incomes increase even more dramatically. Germany, France, and Sweden quintupled their per capita GDPs. Incomes in Italy and Spain grew six fold. Finland's income was multiplied by 7 and Norway's by 8. Japan, Taiwan, or Korea grew by more than tenfold. Even among the not too successful Latin Americans, Argentina performed poorly: between 1928 and 2000 Brazil multiplied its per capita income by close to 5 , Mexico by 4, Chile, Colombia, and Venezuela by around 3. Only Uruguay (2.02) and Peru (2.08) are close to the 1.995 ratio between Argentina's 2000 and 1928 per capita GDP.

By the end of the 20th century, Argentina's story of economic divergence is particularly sad for a country that looked so promising at the century's dawn. In the 10 years following 1900, Argentina had the highest immigration to population ratio in the world - an unequivocal sign of high hopes. That steady inflow of labor did not prevent the country from enjoying, along with Canada, the world's highest per capita growth rate in that decade. Between the eve of World War I and the 1920s, Argentina was very close to being a rich country if it was not already there. Argentina's per capita GDP lagged behind the average of the core Western European countries and Maddison's "Western Offshoots" by less than 20\% — and sometimes by as little as 7\%—between 1905 and 1929. Massive population growth and economic success between 1870 and 1930 combined to multiply Argentina's share in world GDP by a factor of $4 .^{2}$

Disappointing as Argentina's post-1930 performance was, does it really involve an economic puzzle? Perhaps, we should just expect countries to rise and fall. Is it normal for countries that reach the league of the rich to remain in that league? Are there many countries which have, like Argentina, fallen from a per capita GDP of over four-fifths of the level seen in the 12 originally rich nations, ${ }^{3}$ to a per capita GDP level consistently below one-half of their incomes?

\footnotetext{
2 All data from Maddison, in http://www.ggdc.net/maddison/, retrieved March 2010.

3 The group uses GDP per capita measured in 1900, and includes England, France, Germany, their economic hinterland (Denmark, Belgium, Netherlands, Switzerland, Austria) plus the four "Western Offshoots" (USA, Canada, Australia and New Zealand). The thirteenth was Argentina (77.7\% of the richest twelve), and, after a gap, Uruguay (62.5\%), Sweden (62.3\%) and Chile $(61.7 \%)$ followed.
} 
The list is short, and has the peculiarity that all five cases hovered around $40 \%$ of that sample by the year 2000: Uruguay (around 100\% in the 1870s), plus four oil exporters: Venezuela (more than 100\% in 1945-1960), Saudi Arabia (90\% during the first oil shock), Kuwait and Qatar (both of them, more than $400 \%$ in the early 1950s). Three of the five are tiny, with a population less than a tenth of Argentina. All five cases achieved moments of extremely high levels of per capita GDP because of an exceptionally rich endowment of natural resources per person. In the case of Saudi Arabia and Venezuela, petroleum provided the source of natural wealth. In Uruguay, the riches reflected the fact that 213,000 Uruguayans held an average of 24 cattle and 12 sheep each in $1860 .{ }^{4}$

Was that also the case for Argentina? In the next section, we discuss that this possibility as Argentina's per capita GDP during the initial decades of the 20th century was the brief result of a natural resource boom. If Argentina's wealth only reflected the temporarily high price of natural resources, then those natural resources were a misleading indicator of true economic development. According to this hypothesis, natural-resource-based wealth is a far less durable source of prosperity than physical or human capital, and Argentina's wealth primarily reflected an abundance of acreage relative to countries of similar income per head.

Yet, economic theory does not automatically suggest that natural-resource-based prosperity will lead to subsequent poverty. Indeed, the standard growth theory suggests that countries using their natural resources fully can grow faster, ceteris paribus, not slower, than similarly wealthy countries that relied instead on standard investment, because the natural-resource-rich economy still has plenty of space for growth based on factor accumulation. Indeed, if we define modern economies as those where accumulation of capital — physical and human — and technology account for all of the growth in per capita GDP, a corollary of Solow-type models is the prediction of "conditional convergence": countries with lower per capita stocks of human and physical capital, while poorer, should grow faster due to decreasing returns (in countries with lower capital stock the marginal productivity is higher).

Consider two countries with a similar per capita GDP in 1910, one of them with more natural resources and less physical capital than the other, in per capita terms. Call them Argentina and The Netherlands (actually, in 1910, their per capita incomes were the same and they both had a population between 6 and 7 million). By 1910, Argentina had already reached its agricultural frontier, so it perhaps appropriate to consider land a fixed factor - though not an exhaustible one-by that time. Imagine, moreover, a similar technology and savings rate, broadly defined. ${ }^{5}$ If both countries have the same savings rate and the same per capita income, and assuming that they invest what they save (i.e., the closed economy case) in physical and human capital; then, they would both be adding the same amount of capital to their current stock. If both countries have the same rate of population growth, then capital per worker will be increasing by the same amount in both countries. However, because physical capital is initially lower in Argentina than The

\footnotetext{
${ }^{4}$ Uruguayan population in 1860: extrapolation from Maddison's data for 1850 and 1870 using a constant rate of growth. Cattle and sheep from Gran Enciclopedia Rialp, 1991.

5 Taylor (1992), though, argues forcefully that Argentina had a very low savings rate.
} 
Netherlands, and if there are decreasing returns to capital, then Argentina's income per worker should be growing more than that of The Netherlands. A resource-rich country (say, Argentina in 1910) could easily have higher capital productivity and, therefore, grow more than another country that is poorer but more capital intensive (say, Austria-Hungary in 1910). Standard growth theory models would predict that there could be divergence favouring the resource rich.

A simplistic view might hold that population growth will lead to faster reductions in per capita productivity in a more agricultural economy, like Argentina, than in an industrial, urban economy, like The Netherlands. But that view implicitly assumes that the industrial economy is consistently adding capital to match the inflow of workers. There was nothing to stop Argentina from adding capital just as steadily. ${ }^{6}$

This emphasizes the point of the special collection: the stereotypical narrative of Argentina's relative decline (a country exhausting its source of growth, the exceptionally fertile pampas) does not sit well with the benchmark growth model in economics. The motives behind Argentina's decline need to be subtler and include the models, where natural resources can be a curse, as in the literature reviewed in Sachs and Warner (2001). Two- and three-sector models have been central to the debate on Argentina's growth difficulties. ${ }^{7}$ Most of these models address whether Argentina could have grown by persisting in its bet on its natural resources. The alternative view is that capital accumulation and technological advances necessarily required a structural transformation towards a more diversified economy. This structural shift hypothesis then asks whether that transformation would result from a market process or could only take place with government's assistance.

Models in the endogenous growth tradition will differentiate between Argentina and The Netherlands under the conditions described above. For example, Campante and Glaeser's paper in this special collection shows that Buenos Aires had lower levels of physical and human capital than Chicago. In models such as Lucas (1988), the level of human capital is a significant determinant of economic growth, as the rate of increase in human capital depends on its level, through externalities. A similar story could be made of technology or physical capital. Can such a model explain the unstable timing of Argentina's decline, with periods of accelerated divergence (the 1980s) and some of moderate convergence (the 1960s)? The answer is far from obvious.

The more general point is that Argentina's XXth century economic performance is puzzling. There are no straightforward reasons why, contemplating Argentina in 1910 or 1928, one could predict Argentina's unfortunate divergence. Contemporary observers were rosily optimistic about Argentina's future in 1900, the 20s or even as late as the immediate postwar. ${ }^{8}$ Other countries that were resource rich at the start of

\footnotetext{
${ }^{6}$ Interestingly, population growth in Argentina seems to have been higher. In 1910, Argentina's population was $2.4 \%$ of the population of the "richest twelve" (footnote 3); in 2000, it was 6.4\%.

7 The list of explanations in this vein are too numerous to be listed here. Di Tella and Zymmelman (1962) and Díaz Alejandro (1970) are two examples.

8 A well-known quote is from Paul Samuelson: "In 1945 I was a young talented economist. I was at the height of my abilities. If someone had asked me what part of the earth would develop the fastest in the next 39 years, I would have said: Latin America - Argentina or Chile. There is a moderate climate there and a population with European roots... I was completely off the mark." Interview for Der Spiegel, 28:2005.
} 
the 20th century, like Australia and Canada, still enjoy plenty of prosperity. An almost-rich country turned almost poor; Argentina is a likely outlier for many theories of economic growth. We now briefly discuss four primary hypotheses that can account for Argentina's exceptionalism.

\section{Major hypotheses}

In this section, we describe the historical context and summarize four over-arching explanations of Argentina's painful 20th century. These explanations are not mutually exclusive, and indeed, many are linked. They do, however, map out much of the intellectual terrain associated with the standard explanations of Argentine exceptionalism.

\subsection{Just say no to exceptionalism: not rich then; not poor now}

The first hypothesis is that, once we properly measure inputs and outputs, Argentina is not truly exceptional in any interesting economic sense. The hypothesis comes in two versions. The first is that Argentina was not truly rich at the turn of the XXth century. The second is that it is not particularly poor now.

According to the "Argentina was never really rich" view, the country did have natural resources that briefly made it rich when those resources were in high demand, but it did not share the other attributes of advanced countries before World War I. In particular, its human capital, physical capital and access to cutting edge technologies were far below those in other, poorer countries. According to this view, the decades around 1910 should be seen as a brief outlier, and Argentina post-1945 has just returned to the level of wealth implied by its core assets and competencies.

The argument, essentially, is that Argentina's early wealth was temporary in nature, a shock which has more in common with the booms in oil-producing nations during the 1970s than with the more permanent prosperity associated with developed countries. Perhaps, the most controversial variant of this hypothesis is the literal questioning of standard income numbers, such as those from Maddison (1986). Some have argued that Maddison overstates Argentine prosperity at the beginning of the 20th century, and others have argued that he understates Argentina's wealth since the 1960s, because he misses the role played by the expanding informal economy since the 1960s. The implied corrections, however, are significant but not dramatic: while Maddison puts Total GDP in 1900 at 12,100 (in constant pesos; basis: 300,000 in the year 2000), the revised estimate of Gerchunoff and Llach (1998) is 10,800. ${ }^{9}$

Far more common is the view that, even if Argentina was relatively rich, those riches were narrowly concentrated in some groups of the population and were not

\footnotetext{
9 The discrepancy occurs because early figures are estimated working backwards from current estimates (using growth rates) and there were upward corrections to GDP numbers in the 1990's. Note that the revised estimates of Ferreres (2005) are very similar to those of Maddison. For the period before 1900 things are even sketchier; the best available estimates come from Della Paolera (1988) and Cortés Conde (1997).
} 
accompanied by other common correlates of development. For example, Adelman (1994) and Engerman and Sokoloff (1997, 2000) have discussed the high level of inequality in Argentina at the turn of the century, particularly in the agricultural sector and the lack of institutional development, particularly relative to other wealthy nations like the United States or Canada (Solberg 1987). According to this view, the United States managed to share land and prosperity to a much greater degree than Argentina, where large estates where far more common. As such, Argentina should be seen as a less developed nation than the US, managing only to enrich a tiny slice of its population and without the institutional framework to tackle more complicated forms of production.

There is little doubt that Argentina had significantly less education than many other wealthy nations a century ago. For example, the rate of primary school attendance in 1910 Argentina was $48 \%$ of that in France, and $57 \%$ of that in Germany, despite the fact that Argentina was 29 and 14\% richer, respectively, in terms of per capita GDP. ${ }^{10}$ Argentina was catching up in terms of primary school enrollment, but it remained significantly below Western Europe and far below western offshoots, like the US, Australia, and Canada, throughout the pre-World War II period.

Just as pre-World War II Argentina seems to have less human capital than other wealthy nations, it also seems to have had less physical capital, at least if one excludes the great value of its land and livestock. The Campante and Glaeser paper in this special collection compares industrial output and capital stocks in Buenos Aires and Chicago at the beginning of the 20th century. They find that there is a wide gap between the two cities. Value added per worker is far lower in Buenos Aires, and capital per worker is too. In some cases, capital per worker is more than 75\% lower in Buenos Aires at then-contemporary exchange rates.

The lower level of human and physical capital also seems linked to a technology gap between Argentina and many other western countries, at the turn of the last century. The Campante and Glaeser paper documents that Chicago was the home of many cutting edge industries, and the site of many significant inventions (e.g., the skyscraper). The same thing could be said of Detroit (mass produced cars), New York (alternating current), Paris (radioactivity), London (subways, vacuum cleaners), and Berlin (electric streetcars and elevators). By contrast, Argentina was primarily an importer of technologies developed elsewhere.

The Not-Rich-Then hypothesis suggests that Argentina in 1910 should not be compared to other rich countries, because it lacked the key ingredients that make development durable. According to this view, Argentina was essentially an underdeveloped economy made temporarily rich by an abundance of high quality land and better transportation technologies (which were again developed elsewhere). As such, it is not surprising that Argentina had a bad 20th century-it just reverted to form. In a sense, the other hypotheses can be understood as explaining the channels through which Argentina's lack of the early 20th century resources resulted in less economic development.

\footnotetext{
10 Data from Peter Lindert's database: www.econ.ucdavis.edu/faculty/fzlinder/Lindert\%20data\% 20CUP\%20book/App._T._A1_primary_enrol.xls.
} 
The second version of the empirical skepticism towards Argentina's low growth is that the country is much richer now than what GDP figures indicate. Corrections of GDP measures are not uncommon in developing countries, and Argentina is no exception, with a large upward correction in the national accounts implemented in the 1990s. A standard rationale behind such changes is a desire to incorporate the large informal sector that arises when regulations and market limitations proliferate under a relatively weak state. An adjustment of approximately $30 \%$ of GDP for Argentina is not unusual using the "monetary method" (this number comes from Ahumada et al. 2003). ${ }^{11}$ In this spirit, it is possible to argue that the usual approach to measure GDP has to be adjusted when the economy undergoes big changes in the number or quality of available products, or when the tendency of consumers to substitute away from expensive products biases the price index. In this special collection, Gluzman and Sturzenegger explore this approach exploiting the change in trade regime that allowed for increased product variety during the 1990s. Their work suggests large upward revisions of the current levels of GDP.

\subsection{Bad institutions}

A second standard hypothesis for Argentina's decline emphasizes a dearth of good institutions, which are defined as stable and pro-growth set of rules, both in politics and in the economy. Institutionalists may not agree about the perfect political system or the exact balance of legislative and judicial authority, but they share the view that growth depends on having a system in which opportunity to invest and reap the fruits of individual effort are open to everyone; where contracts are enforced by impartial courts; where property is secure and not subject to arbitrary seizure; and where those rules, and the governments that create those rules, are reasonably stable. Typically, stability means that governments only change through tools that are defined in a widely accepted meta-rule such as a constitution. The importance of institutions to economic growth in the context of the New World has been emphasized by Sokoloff and Engerman (1997), while studies of Argentina's institutional performance include Duncan and Fogarty (1984), Prados de la Escosura and Sanz Villarroya (2006), Alston and Gallo (2010) and Aráoz (2013). The index developed by Aráoz (2011) to measure the quality of institutions falls on average after 1930 and becomes more volatile. Acemoglu and Robinson (2008) provide a thorough analysis of the causes and consequences of institutional differences across nations.

On the political side, some dispute whether Argentina was behind other advanced countries around 1900. Argentina was a republic, albeit one with a limited franchise until 1912, and strongly empowered local landowners. The House of Lords was still empowered in the United Kingdom in 1900. Japan and Germany had emperors and strong limitations on the power of democracy.

\footnotetext{
11 The idea, broadly, is to use an estimate of the amount of money held by agents in excess of what they need to finance official transactions (making assumptions about the relative velocity in the shadow and official economy). Another revision in the late $1990 \mathrm{~s}$ updated prices and led to a downward correction.
} 
One sizable difference between the US and the Argentine republic in 1900 was caused by immigration. Both the US and Argentina were magnets for European immigration before World War I. While the proportion of immigrants in the US never exceeded 15 of the total population, immigrants often accounted for more than $30 \%$ of Argentina's population. In the US, urban political machines worked assiduously to turn immigrants into citizens and voters. In Argentina, the path to citizenship was far rockier. Common estimates are that less than $2 \%$ of immigrants became citizens in Argentina, in spite of their economic success. A large, disempowered population can be dangerous to the stability of a budding democracy.

Argentina's path to institutional instability begins in 1916, with the election of Hipólito Yrigoyen. This was a dramatic political shift which replaced the conservative regime by the radical party, and brought into the country's political life a large portion of the middle class. However, 1912 was a watershed year for the US as well, with the election of progressive Democrat Woodrow Wilson. Locally, Yrigoyen looks like a break, but globally, the rise of Argentina's radicals looks more like an international leftward trend. The radicals held on to power until 1930, while the US and the UK moved back to the right after World War I.

However, the real watershed was in 1930 when a military coup brought down Yrigoyen's second government. Crucially, the Supreme Court would later recognize as valid the legislation issued by the illegitimate government stemming from the 1930 coup. Unlike the United Kingdom or the western offshoots, Argentina had accepted regime change by the bayonet instead of the ballot.

Argentina returned to a democracy of sorts with the 1931 election, but the radicals were banned from participation. As the great depression impacted world trade, a more conservative regime was put in place by an elite-dominated coalition known as the "Concordancia." Argentina's first coup had destigmatized military takeovers, and another nationalistic military coup in 1943 ousted the conservatives.

The 1943 coup began the strange career of Juan Perón. The new government's Secretary of Labor became popular by enacting a stream of pro-labor legislation. Perón was later voted president in open and relatively fair elections in 1946, and reelected-after changing the Constitution to allow for a second term-in 1952. Although Perón began as a member of a militarily installed regime, his government increasingly came into conflict with the Armed Forces. Perón's policies were populist and authoritarian, and unpopular with the far more liberally (in the classical European sense) minded middle classes. The middle classes increasingly saw the Armed Forces as their best shot for regime change.

A failed attempt by part of the military to kill Perón, through an air-strike in Plaza de Mayo, resulted in more than 300 hundred deaths. The sense of instability consequently increased. Perón was deposed by Argentina's third successful military coup in 1955 .

Frequent switches from military to civilian rule marked the period from 1955 to 1983. The periods of military control were 1955-1958, 1962-1963, 1966-1973, and 1976-1983. In between, elections often banned the Peronist candidates. Terms were short and the military still exerted significant influence, often suppressing labor unions. The combination of restrictions on the labor movement, limited democracy, and burgeoning nationalism led many to question the legitimacy of the system. 
An attempt to co-opt a pragmatic faction of the union leadership under the notion of "Peronism without Perón" ended with a radicalized opposition that turned to violence. In 1969, a riot in the city of Córdoba left 14 casualties and created a crisis in the military leadership. An urban guerrilla movement that reached 5000 at its zenith in 1975 became increasingly violent (see, for example, the estimates presented in Moyano 1995). Political assassinations, kidnappings of businessmen, intimidation, and chaos became common as the "dirty war" began. In 1975, one political death took place every $19 \mathrm{~h}$ (Goti 1996). After a military coup in 1976 (the sixth in 36 years), the military repressed the insurgents through illegal means that included torture and the forced disappearance of approximately 9000 people without trial. $^{12}$

All told, Argentina had 53 years of military coups and instability from 1930 to 1983. Yet, since then, Argentina has functioned as a democracy and transitions have been almost uniformly peaceful. Only in 2001-2002 was political change set off by widespread riots, but, after all, that has also happened in Western Democracies, like France. Four figures-Alfonsín, Ménem, and the Kirchners-dominated the first three decades of democracy. Since 1983, Argentina's commitment to democracy has been solid. Its commitment to the rule of law or pro-growth economic policies is more debatable.

Did Argentina's political instability generate policy outcomes that explain the country's poor economic performance? Prior to the Ménem administration, for example, democratic governments tended to be more protectionist and to fuel wageled inflation, while military governments were friendlier to exports and usually devalued soon after a coup. Perhaps, the see-sawing between these two types of regimes deterred investment.

Inflation was pervasive during the whole period 1946-1990, arguably for political reasons, and became a permanent feature of Argentina's institutional scene. These rapid price changes may have undermined the confidence in contracts in general. Faith in contracts was surely reduced by Argentina's default on its public debt in 1890 (with a constitutional government), 1982 (military government), and 2001 (democracy). That breach of the rule of (economic) law, however, seems to have been independent of the political regime in place.

Democratic stability has not necessarily meant legal protection for investors. Banking depositors had their terms forcefully changed in 1990 and 2001 by democratic governments. Waves of explicit expropriations also occurred during democratic governments, such as Perón (public services), Illia (oil), and Kirchner (both).

Diaz-Alejandro (1970) famously argued that political instability adversely affected Argentina's economic performance during the 1970s. Four essays in this special collection, by Alan Taylor; Brambilla, Galiani and Porto; Di Tella and Dubra; and by Galiani and Somaini all explore political factors which may explain Argentina's economic woes. They together build a case that instability led to policy

\footnotetext{
12 This is the estimate provided in the report by The National Commission on the Disappearance of Persons (Comisión Nacional sobre la Desaparición de Personas, CONADEP). Given the absence of legal, documented trials, these estimates are often questioned.
} 
choices which diverged from those selected in more advanced countries. They emphasize different aspects of instability, ranging from political beliefs to tariffs and protections, but their stories do not conflict. Many factors came together in Argentina's political economy to cause the country's troubled 20th century.

\subsection{Bad international shocks}

A third explanation for Argentina's economic malaise is external shocks. Naturally, that view is particularly popular among many of Argentina's own leaders. External shocks can take the form of negative shocks to the terms of trade in global markets, for goods. Shocks to the availability of global capital investment into Argentina are a second example of such a shock.

Until, the First World War global conditions in both goods and capital markets strongly favored Argentina. The world placed a high premium on Argentina's agricultural output. International finance helped bankroll the investments in infrastructure needed to support its agricultural export business.

Over the rest of the 20th century, technological advances in agriculture reduced the value of Argentina's fertile agricultural land. The real price of wheat, then as now a major Argentine export, in the US fell by 75\% between 1920 and 2005. In a world that grew richer, Engel's law meant that external demand for food grew less than demand for other goods.

Adverse short-term shocks accompanied these secular trends away from high agricultural prices. The world turned more inward in the 1930s and protectionist rules remained in agricultural goods, despite the postwar move towards openness. During the middle decades of the 20th century, foreign capital played a far less central role in the Argentine economy than it had during Argentina's late 19th, early 20 th century boom.

In many cases, it is hard to view the external shocks as being completely independent of internal political and economic processes. The global trend against agriculturalists did not hurt other big farm economies, like the US and Australia, because they diversified into other products. Moreover, the declining availability of global financing for Argentine development surely reflected, at least in part, political instability within the country. Finally, and particularly interestingly, "bad luck" in external shocks could have led to harmful policy choices and political instability, which in turn restricted the ability to respond well to external shocks.

Raul Prebisch famously argued that there was a long run trend in the terms of trade, between the 1870s and the 1930s, which adversely affected primary goods producers such as Argentina. Those ideas provided intellectual fodder for Perón's state-sponsored industrialization. More recently, Hadass and Williamson (2003) confirm Prebisch's evidence on the terms of trade, but suggest that declining terms of trade did not really adversely impact Argentina until the 1920s.

In the late 1920s, foreign markets for Argentine products stabilized, but the situation again deteriorated during the global downturn of the 1930s. During those years, Argentina was simultaneously struck by a decline in the income of their global customers and a renewed enthusiasm for tariff protection, exemplified by America's 1930 Smoot-Hawley Tariff. The onset of the depression also meant that 
Argentina could no longer finance investment by running current account deficits, which, according to Taylor (1992), was a fatal blow for a country, whose savings rate was not particularly high by international standards.

World War II and its aftermath boosted demand for Argentine produce, but soon afterwards terms of trade declined once more (Cavallo and Mundlak 1982). Argentina faced continuing restrictions on trade in agriculture, which were only partially ameliorated by its signing the General Agreement on Trade and Tariffs in 1967. The fact, first postulated by Engel, that the share of income spent on food declines with income rise also implies that economies exclusively relying on agriculture should account for an ever-decreasing share of the global economy, as the world gets richer.

Moreover, technological breakthroughs, like the Green Revolution, massively increased the productivity of marginal agricultural areas. Improving productivity of marginal land may have reduced the ability of Argentina to grow by exporting to areas agriculturally less productive. There is surely some truth to the notion that global economic changes helped contribute to Argentina's relatively slow rate of growth during the 20th century. Only recently have terms of trade recovered somewhat from the long run downward trend.

However, the impact of downward external shocks is always, at least somewhat, shaped by the policy response, which is shaped by the knowledge, incentives, and beliefs of voters and political leaders. The Di Tella and Dubra essay emphasizes the difficulty in agreeing on the interpretation given to some of these shocks when lack of trust prevails in an unequal and politically divisive society. The essay documents how these changes were interpreted by one of the main political forces (Peronism) and how this helped boost economic populism. Protectionism and the growing antiexport bias of the country interacted with initial political and economic conditions, such as the small size of Argentina's internal market, and possibly pushed firms towards rent seeking and corruption. As external opportunities declined, the role of the state increased. Often, the best business was not the efficient production of goods for external markets, but to lobby the government for public contracts. As businesses looked inward, the pressure for inward-looking interventionism increased.

Basic trade models, such as Stolper-Samuelson, emphasize that some factors of production may be made worse off by trade, and this seems quite relevant for Argentina. The negative impact of trade on some parts of the economy can help explain why protectionist policies were so popular in sectors of the Argentine economy (see Díaz-Alejandro 1988). This process is documented in the essay by Brambilla, Galiani, and Porto. Moreover, the inward-looking policies that Argentina followed after World War II do seem to have produced a striking reduction in income inequality, as Alvaredo, Cruces, and Gasparini document in their essay in this special collection.

However, the Stolper-Samuelson logic does not explain Argentina's bumpy process of integration into world markets, or the long persistence of Argentina's isolation. The Galiani and Somaini essay shows that these facts can be understood by adding a non-tradable sector into the classic model and by adding frictions in the mobility of capital across sectors. Indeed, an important contribution of this paper is 
to show the significance of connections between external economic shocks and internal political dynamics.

Every nation was at one point dominated by agriculture, but the more successful ones, including the United States, were able to transform themselves. In spite of significant import-substituting pro-manufacturing policies after the 1940s, Argentina did not move quickly into other non-agricultural products. The country failed to develop into a significant industrial powerhouse, with little technological innovation and apparently slow progress in the development of managerial expertise. While Argentina was as rich as much of Europe as late as 1950, European countries managed to grow much more rapidly, primarily through the development of industry. Even more remarkably, East Asian economies, such as Japan and Korea, which were far poorer than Argentina through the 1960s, managed to transform themselves far more rapidly.

Why did Argentina fail to modernize along this dimension? An economic view is that Argentina's factor endowments were not as inviting to industrial investment as elsewhere. Argentina was neither a labor-abundant country for low wage manufacturing, nor did it have, as discussed by the Campante and Glaeser paper, a particulary educated workforce compared to the industrial leaders. According to the Barro-Lee data, average years of schooling in Argentina increased from slightly under 5 years in 1960, to 6.6 years in 1980 and 8.5 years in 2000. The "advanced country" average in their data set is more than 7 years in 1960, 8.86 years in 1980, and 9.8 years in 2000. Japan had 6.8 years of schooling in 1960 when it was still considerably poorer than Argentina, 8.2 years in 1980 and 9.7 years in 2000. Given the strong connection between growth and human and physical capital accumulation (Mankiw et al. 1992; Barro 1992), perhaps Argentina's lackluster growth performance is not that surprising.

Moreover, technological innovation also seems to have been relatively slow in Argentina during the last 40 years. For example, the United National Industrial Development Office classifies the share of manufacturing value added accounted for in medium and high technology production. ${ }^{13}$ In $2005,25.7 \%$ of Argentina's manufacturing value added came from these more sophisticated operations, as opposed to $41 \%$ in Canada and $61 \%$ in Germany. The share of medium and high technology production in manufacturing exports in 2005 was $31 \%$ in Argentina, $57 \%$ in Canada, and $72 \%$ in Germany.

\subsection{Bad policies}

The fourth hypothesis emphasizes politics and blames bad economic policies and harmful intervention instituted by government after government. Different versions of this hypothesis point to different policy culprits. Some scholars emphasize unsustainable short-run macroeconomic policies pertaining to budget deficits, inflation, or exchange rates. Others note the adverse incentives that damaged growth in the long run, such as protectionism and inefficient public production. In general, these policies chosen during the second two-thirds of the 20th century in Argentina

\footnotetext{
13 https://www.onudi.org.ar/fileadmin/user_media/Publications/IDR_2009_print.PDF.
} 
can be contrasted to the laissez-faire context prevalent until that time. Indeed, the more interventionist and highly volatile approach of economic policies after the depression is often blamed for Argentina's relative decline.

The tide for government intervention came in Argentina in successive waves. After 1916, Yrigoyen enacted policies that some economists see as being detrimental to growth, like minimum wage laws, but there is little evidence that Argentina suffered during this period. The 1930s saw more interventionism, partially as a response to the depression and partially in response to rising population levels. Public works were started; import duties were increased; and a system of multiple exchange rates favored manufacturing activities over agriculture. The resulting industrial growth led rural workers to migrate to urban centers and helped shift the composition of labor organizations. Real wages remained stagnant, while the perception of government concessions to foreign trading partners, principally Britain, irked nationalists.

Interventionism reached its height with Perón. As a Secretary of Labor, he enacted a comprehensive set of pro-labor laws that included a scheme to establish and periodically adjust minimum wages, often leading to increases in real terms; yearly paid vacations; retirement and health insurance benefits; and an annual mandatory bonus equal to an additional month's salary. He also instituted the Agricultural Worker Statute (Estatuto del Peón) in the late 1944, which outlined the specific rights and obligations of both rural workers and employers. This law was perceived as a defiance of the landed elite. In 1945, he enacted the Law on Professional Associations, which gave his Labor Secretariat veto power over the formation of new unions. By the end of his tenure, Argentina had advanced to a world leader in labor legislation (see, for example, the description in D'Abate 1983).

The 9 years of Perón's presidency starting in 1946 witnessed intense political polarization. Perón enacted policies that antagonized the rich. He continued a set of pro-union policies, and between 1946 and 1954 union membership increased from 880,000 to 2.5 million, which amounted to $42.5 \%$ of all workers (Smith, 1991). He also nationalized railways and banks, took public control over the grain trade, engaged in protectionism, and chose not to join international institutions like the General Agreement on Tariffs and Trade.

In his essay, Taylor emphasizes the significant cost to Argentina of inwardlooking policies, both through the increase in the prices of capital and input goods, and the decline in technological transfer from abroad. While many other developing countries followed Alexander Hamilton's suggestion of using protectionism to nurture nascent manufacturing industries, Argentina was particularly aggressive, perhaps because of the Stolper-Samuelson-related effects discussed by the Brambilla, Galiani, and Porto essay. Moreover, the popular pressure for closing the economy will be stronger if the losing factor (land) is concentrated in a few hands, a crucial point stressed by Díaz Alejandro (1970).

While some of the most interventionist of Perón's measures were removed by successive governments in 1955-1976, the general protectionist stance remained, and was even strengthened during the "developmentalist" attempt of Frondizi (1958-1962). State intervention, including public provision of most public services, 
was no free lunch, and the fiscal cost of attempting an inward-looking industrialization fueled inflation in the postwar decades.

After the 1976 coup, a pendulum in economic policies ensued: a move towards openness in trade and capital flows in the late 1970s was reversed during the 1980s. Inflation remained stubbornly high during 1975-1990, often above 100\% per year, coinciding with the fastest relative decline of Argentina, as shown in Fig. 1.

Again in the 1990s Argentina moved, more decisively, towards privatization, free trade and unrestricted capital flows. The 2001 crisis, the harshest in Argentina's history, contributed to the unpopularity of those policies, which were gradually reversed during the Kirchner administration-including some nationalizations and the return of import permits and exchange rate controls. The debate on the causes of the 2001 crisis (which included a sizable devaluation, a debt default and a confiscation of banking deposits) mimic the larger one on Argentina's long-term decline. Again, the problem could be the laxity of economic rules or an unfortunate combination of international shocks (terms of trade, devaluation by Brazil and others, and a sudden stop of foreign funds) or institutional (with corruption playing a key role in the break up of the ruling political coalition under an exchange rate peg) or economic policies, including fiscal largesse and an unsustainably fixed exchange rate. Once more, it is hard if not impossible to precisely attribute outcomes to each of these forces.

\section{The plan of the collection}

This special collection has seven papers, examining different aspects of Argentina's performance and of the hypotheses discussed above. We begin with one essay about Argentina at the dawn of the 20th century-comparing Argentina and America, or more specifically Buenos Aires and Chicago. We then include three papers on Argentina's place in the global economy. These essays describe the changes in Argentine trade, explore why those changes occurred, and then discuss how much this mattered for growth. We then include two essays on Argentine politics that focus on Peronism, income inequality and the relative degradation of Argentine institutions over the 20th century. We end with an essay about growth in incomes over the last 20 years.

The first essay, by Campante and Glaeser, contains two different parts. The first part focuses on two cities-Buenos Aires and Chicago. These two places looked extremely similar in 1900 and played similar functions in the economies of Argentina and the American Midwest. Yet, there were significant differences in the two cities, even in 1900, for Chicago was far more educated, far more capital intensive and more clearly on the world's technological frontier.

The paper's second section is a broad statistical exercise that asks whether Argentina's economic growth between 1900 and 2000 can be "explained" by the country's attributes as of 1900. As there is an extremely strong connection between education and growth over the 20th century, Argentina's relatively low level of education as of 1900 can explain most of Argentina's poor growth performance over the century. The statistical exercise also suggests that the strong connection between 
education and growth, both across the world and in Argentina, may reflect the fact that lower levels of education are related to dictatorship and political instability, which in turn seems to hamper economic prosperity. However, while Argentina's 20th century economic experience is not all that surprising, given that its early prosperity was not accompanied by other forms of development, that fact still doesn't really answer the key question-what went wrong?

Argentina's prosperity in 1900 was intimately related to its role as a great global exporter. Its relative decline post 1930 is related to a significantly more closed up economy. Thus, a good follow-up to the "lack of early human capital" hypothesis pays significant attention to Argentine trade. Thus, the next essays of this special collection focus on trade, starting with the paper by Campante and Glaeser. Then we have Alan Taylor's paper, which assesses the overall role that trade played in Argentina's economic progress. Using a standard, open economy model, Taylor suggests that a 50\% increase in trade costs should have reduced Argentina's income by about $20 \%$ in the long run. That reduction is primarily due to increased cost of important inputs into Argentine production. While this is not far from the whole story, it does emphasize that, quantitatively, trade can be an important component of Argentina's missing prosperity, a theme of several of the articles in this special collection.

Taylor also performs some illustrative calculations that suggest that underinvestment in capital has also played a big role in Argentina's slower growth. According to some estimates, the marginal product of capital may be twice as high in Argentina as in the US, which suggests that Argentina's incomes might be $25 \%$ lower because of missing capital. Taylor then points us to political factors, such as instability, which may have led to this underinvestment in capital.

The next essay on trade, "Sixty Years of Solitude" by Brambilla, Galiani and Porto, examines the changes in openness in Argentina over the century. The paper documents three clear epochs in the 20th century Argentine history: an early era of openness until 1930, a subsequent 60 year period of relative economic isolation, and a post-1990 opening of the economy. Between 1929 and 1940, the share of exports plus imports relative to Argentine GDP dropped from almost $40 \%$ to below $15 \%$.

The decline of trade during the 1930s reflected both external shocks-a global depression-and trade policies, like substantially higher tariffs. Gradually, Argentina adopted a series of import-substituting policies aimed at strengthening its domestic producers, and these seem to have cut the country further off from the global economy. These policies were only dropped in the 1990s when their failure had become too obvious to ignore. This emphasizes another theme of Argentina's missing prosperity: the selection of policies often contributed to the country's economic predicament.

The third paper on trade, by Galiani and Somaini, attempts to make sense of this long period of solitude arguing that there is path dependence in trade policies. With favorable terms of trade, the economy is dominated by agriculture and services, and there is a consensus for free trade. Adverse shocks to the country's trade possibilities ignite an industrialization process oriented towards the domestic market, but after the shock subsides, the consensus for free trade is broken. Vested interests in the manufacturing sector benefit from and support protection for their 
output. The size and power of these interests increase as anti-trade policies are enacted and the sector grows. According to this view, Argentina essentially got caught in an anti-trade trap: adverse trade shocks created sectors that supported protectionism, which became more powerful as the country became more inward oriented.

If this anti-trade trap impoverished the nation, even though it benefitted some industries, then we must understand why Argentina could not produce a beneficial political bargain. Indeed, one explanation for why Argentina got caught in this trap and other countries did not, is that Argentine political institutions were too weak to produce a welfare-enhancing bargain. Galiani and Somaini contrast the Argentine liberalization process with the Australian, where the protected industries received other, less socially costly, benefits in exchange for accepting lower trade barriers.

According to this view, there are several layers of interactions between shocks and policies. In particular, Argentina's trade policies are intimately connected to the external shocks and the relative strength of the different political coalitions that emerge, given the country's institutions. These interplay between shocks and policy, depend in turn on how shocks and economic events are interpreted, and on people's beliefs concerning the relevant policy elasticities. If professional economists seldom agree on the magnitude (and sign) of these forces, it is no wonder that policy reactions depend heavily on the narratives that political entrepreneurs provide.

Accordingly, the fifth and sixth essays in this special collection turn to Argentine politics and institutions. Peronism has played a central role in Argentina since the early 1940s, and the Peronist Justicialista party has dominated both the legislature and the executive branch of government since 1989. However, what is Peronism? In addition, what does it imply for policy selection? Di Tella and Dubra begin by analyzing the speeches of Juan Perón in the 1940s. They find that a core aspect of his rhetoric is that neither luck nor individual effort is responsible for people's economic outcomes. Instead, Perón argues that people's poverty reflects the actions of outsiders who, with the help of the local elite, are able to implement their nefarious purpose. Perón's rhetoric, of course, served to justify his actions, including trade barriers (which supposedly protected Argentina against malignant foreign forces) and nationalization (which handled the malefactors within the country). This worldview seems to have persisted in Argentina, even though it is no longer particularly associated with the Peronist party.

Di Tella and Dubra find that most of Argentina's electorate in the 1990s was on the left of the political spectrum: both Peronist and non-Peronist voters are more likely than American Democrats to say that poverty reflects an unfair society (rather than laziness), and of course, far more likely to hold those opinions than American Republicans. They are also more likely to report believing that a few big interests run the country. Interestingly, within Argentina, the Peronists are no longer the party with particularly leftist ideas. The non-Peronists, who are typically wealthier and more educated than the Peronists, are rather more likely to have "leftist opinions". ${ }^{14}$ The ideas that Perón espoused in the 1940s, that minimize the role of

\footnotetext{
14 Perhaps the Argentine counterpart of what Tom Wolfe, reflecting on a fundraising party for the Black Panthers at Leonard Bernstein's Park Avenue duplex, called "radical chic".
} 
individual autonomy, have become ubiquitous in Argentina and even more common among the opponents of Peronism.

The essay by Alvaredo, Cruces and Gasparini looks at one of the determinants of these Peronist beliefs: Argentine income inequality. They have put together comprehensive tax-based data on incomes earned by the population as a whole and by the richest Argentines. Through the early 1940s, Argentina remained a stunningly unequal nation. The richest $1 \%$ of the population earned $25 \%$ of the country's income, which is far higher than the US even during the great depression. There was something real behind Perón's conspiratorial narrative. Between the 1940s and 1970s income inequality in Argentina plummeted, and by the 1970s, Argentina was no more unequal than other developed countries. Over the last 30 years, Argentine income inequality seems to have risen substantially, even more than countries like the US. One interpretation of these facts is that Argentina's midcentury policies achieved a very real objective-reducing inequality. Unfortunately, they also seem to have done so at a significant cost.

The last research paper in this special collection considers the growth of Argentina since liberalization in the 1990s. Many critics have argued that despite the economy's opening, growth has been lackluster. The paper by Gluzmann and Sturzenegger challenges this view. They present data suggesting that price indices have been badly mismeasured over the past 25 years, and in particular, prices have not been corrected adequately for the improvement in product quality and variety. Using data on food consumption, they provide suggestive evidence showing that Argentina has actually gotten much wealthier since liberalization. This provides a somewhat upbeat ending to the special collection. If their conclusions are correct, then Argentina did really turn the corner in the 1990s and is now headed for a significantly brighter future.

\section{Conclusion}

The 20th century economic history of Argentina is a great drama filled with momentous actors, like Perón, and seemingly full of missed opportunities and extreme policy choices. The trade essays in this special collection, for example, leave little doubt that the country erected a set of trade barriers that would eventually prove quite costly to Argentina's economy. The Taylor essay suggests that other interventions, and the political uncertainty that surrounded them, were similarly problematic. Institutional decay also played a big role.

Yet, Argentina in 1900 was not the US. It faced constraints and problems that were not so prevalent in other wealthy countries. Argentina had less education, a less well-developed industrial sector and more inequality. Throughout the world, these country characteristics have often been associated with costly policies that seem to deter economic performance. Education seems to support democracy, and inequality is practically an invitation for redistribution that reduces the incentives to invest. This does not mean that Argentina could not have done better, but that a starting fact explaining Argentina's exceptional underperformance is that the true starting level of wealth, broadly measured, is considerably lower than what has 
previously been assumed. It certainly was lower than what Parisians of the $1900 \mathrm{~s}$ meant when they moaned "riche comme un Argentin", which means that at least some of her "failures" are comprehensible.

However, a lower starting point, and even a higher ending point if one accepts that recent GDP figures have to be adjusted upward to take into account the effect of increased product variety, does not fully explain Argentina's predicament over the last one hundred and fifty years. To make further progress we need to give some role for the country's odd choice of policies over the years. Accordingly, several essays in this special collection describe how a succession of Argentine governments picked policies that appeared not to be designed to maximize growth. At one level, voters came to believe that the rich elites were not particularly productive and caring, and came to demand policies that harmed them. Populism and political instability ensued, and private investment suffered. Part of Argentina's decline is explained by voter's beliefs regarding the unproductive Argentine elite and how they become rich through corruption and favoritism, instead of hard work and creativity.

This process introduces the possibility of poverty traps: a shock may lead people to believe that the rich are just lucky and the poor are simply the product of an unfair society. These beliefs, as well as income inequality, then lead voters to demand policies to redistribute some of that "unfair" income. Perón's popularity is in part explained by these forces, as well as by the initial economic success of his interventionist policies. Interestingly, such policies might introduce a vicious cycle particularly in a country such as Argentina, where there is also government failure and administrative corruption, leading to further demands for intervention and redistribution. Of course, reforming the corrupt government is one force that eventually comes into play. However, it is possible that anger against the rich who benefited from those corrupt policies is a powerful, persistent force leading people to vote for interventionist policies that are designed to bring about "fairness" rather than maximize material income.

Several of the essays in this special collection focus on one specific policy: protectionism. One reason is its central importance in the country given its proven ability to export primary products from an early stage. Another reason is that successful firms in a closed economy soon find that they can cover the internal market. If exporting is not attractive, they quickly turn to exploiting their connections selling to the government, fostering the perception that they have been unfairly helped. Thus, a closed economy is particularly receptive to anti-capitalist rhetoric. Accordingly, the essays in the special collection emphasize the role of external shocks and policy choices leading to the remarkable reversal of the laissez faire, low tariff regime by the middle of the XXth century.

While such a policy shift was not uncommon, particularly in Latin America, both its economics and its political economy were somewhat more perverse in the case of Argentina. First, as underscored by Galiani and Somaini in this special collection and Gerchunoff and Llach (2009), in an argument going back to Díaz Alejandro (1970), Argentina's peculiar endowments made protectionism a political winner, as it raised real wages, particularly in terms of food consumption. Argentina lacked, however, both the scale and the factor endowments for a successful inward-looking, 
autonomous industrialization. Argentina's incomplete postwar industrialization, dependent on foreign inputs and capital goods, soon stalled against the foreign exchange constraint imposed by stagnant exports. Starting in the 1970s, the benefits of a more open trade policy were superseded by the perils of real exchange rate appreciation, in a context where external indebtedness served to compensate in the short run for the distributional effects of trade openness. Those attempted shortcuts to economic prosperity were understandable in a country anxious to regain its former luster, but ended up contributing to two major debt crisis, in 1981 and 2001.

The essays in this special collection develop these ideas, and point to powerful path dependence in policies and institutions, and even in beliefs.

Open Access This article is distributed under the terms of the Creative Commons Attribution 4.0 International License (http://creativecommons.org/licenses/by/4.0/), which permits unrestricted use, distribution, and reproduction in any medium, provided you give appropriate credit to the original author(s) and the source, provide a link to the Creative Commons license, and indicate if changes were made.

\section{References}

Acemoglu D, Robinson JA (2008) Persistence of power, elites, and institutions. Am Econ Rev 98(1):267-293

Adelman J (1994) Frontier development: land, labor, and capital on wheatlands of Argentina and Canada, 1890-1914. Oxford University Press

Ahumada H, Canavese A, Canavese P (2003) Estimación del Tamaño de la Economía Oculta por Medio de la Demanda de Circulante: Una Revisión de la Metodología con una Ilustración para Argentina. Revista de Análisis Económico-Economic Analysis Review 18(1):103-115

Alston LJ, Gallo AA (2010) Electoral fraud, the rise of Peron and demise of checks and balances in Argentina. Explor Econ Hist 47(2):179-197

Aráoz MF (2011) La calidad institucional en Argentina en el largo plazo

Aráoz MF (2013) La calidad institucional en Argentina en el largo plazo. Revista de Historia Económica/ Journal of Iberian and Latin American Economic History (New Series) 31(01):73-109

Barro RJ (1992) Human capital and economic growth. Proceedings, Federal Reserve Bank of Kansas City, pp 199-230

Cavallo D, Mundlak Y (1982) Agriculture and economic growth in an open economy-the case of Argentina (Vol. 36). Intl Food Policy Res Inst

Cortes CR (1997) La economía argentina en el largo plazo (siglos XIX y XX). Editorial Sudamericana

D’Abate JC (1983) Trade Unions and Peronism" in Juan Perón and the reshaping of Argentina. Turner F, Miguens JE (eds) University of Pittsburgh Press

Della Paolera G (1988) How the argentine economy performed during the international gold standard: a reexamination. Doctoral Thesis, University of Chicago

Di Tella G, Zymelman A (1962) El desarrollo económico de los espacios abiertos. El Trimestre Económico 29(116 (4), 622-633

Diaz-Alejandro CF (1970) Ensayos sobre la historia económica argentina. Amorrortu

Díaz-Alejandro CF (1988) Trade, development and the world economy: selected essays of Carlos F. DíazAlejandro. B. Blackwell

Duncan T, Fogarty J (1984) Australia and Argentina: on parallel paths. Melbourne University

Engerman SL, Sokoloff KL (1997) Factor endowments, institutions, and differential paths of growth among new world economies. How Latin America Fell Behind, 260-304

Ferreres OJ (2005) Dos Siglos de Economía Argentina, 1810-2004: historia argentina en cifras. pp 1-692. Buenos Aires, Fundación Norte y Sur

Gerchunoff P, Llach L (1998) El ciclo de la ilusión y el desencanto: un siglo de políticas económicas argentinas. Ariel Sociedad Económica, Buenos Aires

Goti JEM (1996) Game without end: State terror and the politics of justice. University of Oklahoma Press 
Hadass YS, Williamson JG (2003) Terms-of-trade shocks and economic performance, 1870-1940: prebisch and singer revisited. Econ Dev Cult Change 51(3):629-656

Lagos M, Juan L (2011) Claves del retraso y del progreso de la Argentina. Editorial Temas

Lucas RE (1988) On the mechanics of economic development. J Monetary Econ 22(1):3-42

Mankiw NG, Romer D, Weil DN (1992) A Contribution to the Empirics of Economic Growth. Q J Econ 107(2):407-437

Moyano MJ (1995) Argentina's lost patrol: armed struggle, 1969-1979. Yale University Press

Prados de la Escosura, Leandro, and Isabel Sanz Villarroya (2006) Contract enforcement and Argentina's long-run decline

Sachs JD, Warner AM (2001) The curse of natural resources. Eur Econ Rev 45(4):827-838

Smith WC (1991) Authoritarianism and the crisis of the Argentine political economy. Stanford University Press

Sokoloff KL, Engerman SL (2000) History lessons: institutions, factors endowments, and paths of development in the new world. J Econ Perspect 14(3):217-232

Solberg CE (1987) The prairies and the pampas: Agrarian policy in Canada and Argentina, 1880-1930. Stanford University Press

Taylor AM (1992) External dependence, demographic burdens, and Argentine economic decline after the Belle Epoque. J Econ Hist 52(04):907-936 